\title{
Kliuchevskoi volcano diary
}

\section{Numerous ash layers deposited at the slopes of Kliuchevskoi volcano provide a detailed and continuous record of its explosive activity during the last ca. 10,000 years}

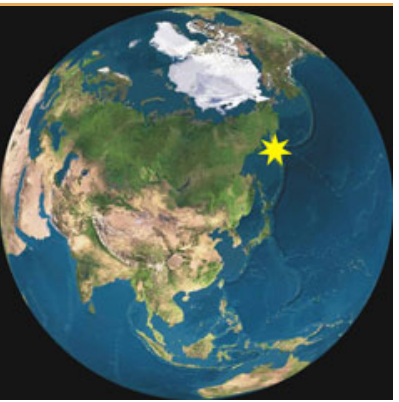

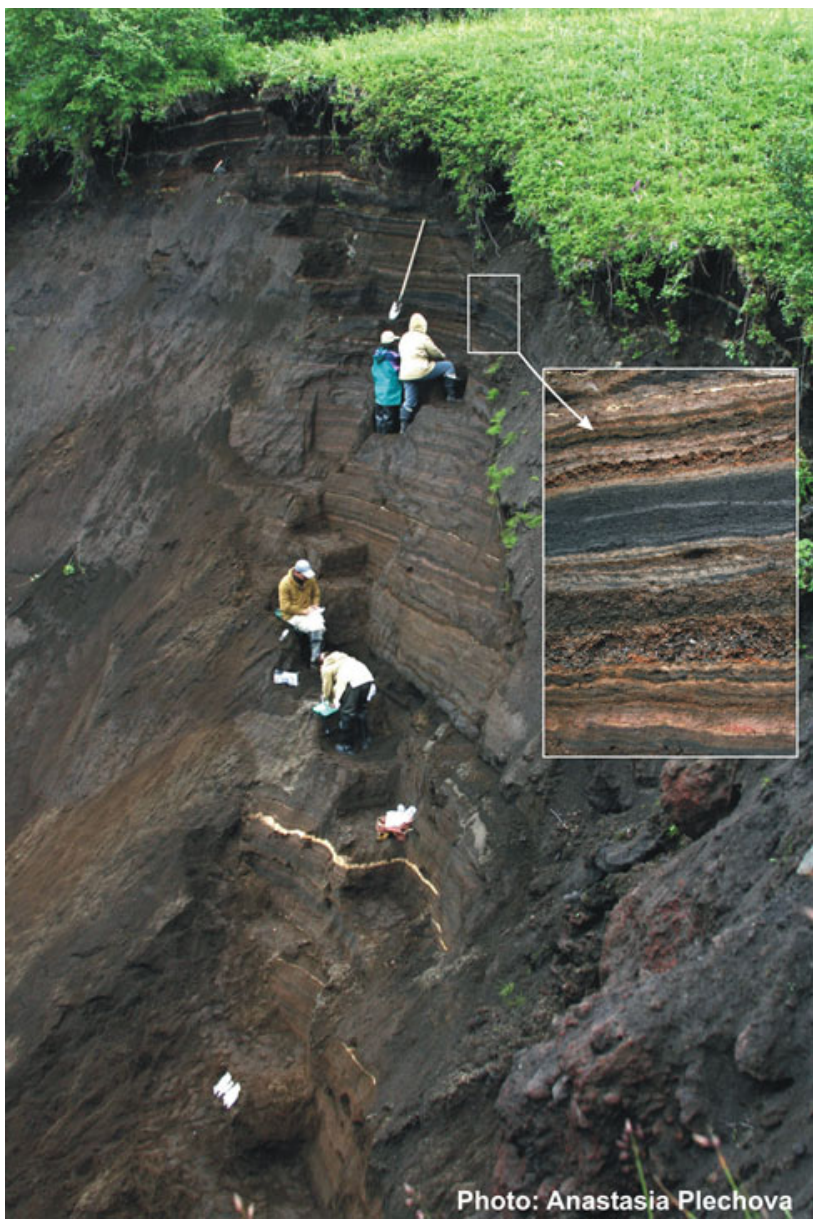

A magnificent, almost 5-km high Kliuchevskoi volcano in the Kamchatka Peninsula, Russia, belongs to a volcanic arc that forms the northwestern part of the Pacific Ring of Fire. Kliuchevskoi volcano is one of the most productive volcanoes on earth and erupts on average about $90 \mathrm{Mt}$ of magma every year. Ash clouds shooting from the volcano reach an altitude up to $20 \mathrm{~km}$ and regularly affect air traffic between SE Asia and North America. The volcanic ash (tephra) of

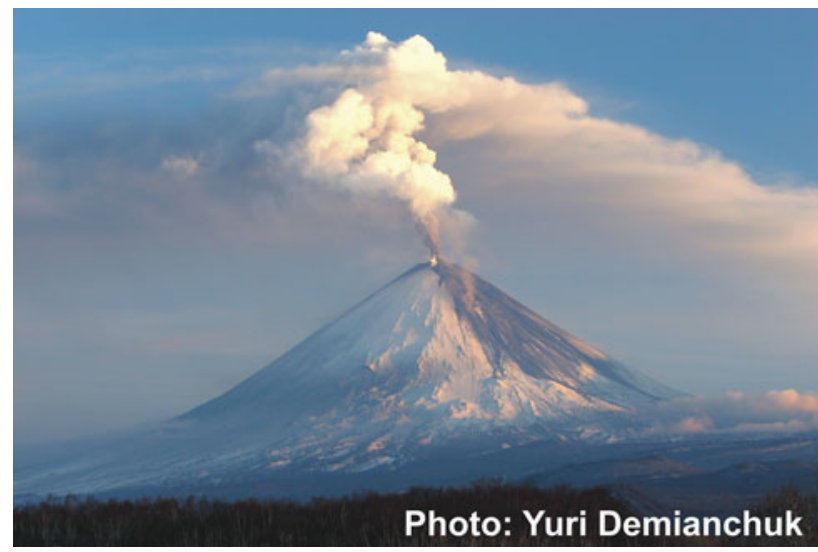

Kliuchevskoi eruptions accumulates on its slopes and provides a unique record of its past explosive activity for the last ca. 10,000 years.

Site $\mathrm{K} 7-\mathrm{T} 1\left(\mathrm{~N} 56.1464^{\circ} \mathrm{E} 160.8241^{\circ}\right)$ is located in a river bank $\sim 15 \mathrm{~km}$ from the Kliuchevskoi crater. It exposes a $12 \mathrm{~m}$ thick sequence of hundreds of Kliuchevskoi ash layers. Dark mafic Kliuchevskoi tephras are interbedded with light-colored silicic ash layers from distant volcanoes. With the help of these regional marker tephras, which have been ${ }^{14} \mathrm{C}$ dated elsewhere (Braitseva et al. 1997), the past Kliuchevskoi eruptions can be dated with a precision of 50-100 years. Being accumulated during the entire Holocene at a rate of about $1 \mathrm{~mm}$ per year, this tephra sequence represents one of the longest and highest resolution records of explosive volcanism in Kamchatka.

Detailed geochemical studies of the site have been undertaken within the KALMAR project (http://www.kalmar.ifm-geomar.de/) funded by the Russian and German Ministry for Education and Research. The studies are aimed at the reconstruction of the eruptive history of Kliuchevskoi and correlation of the latter with regional and global record of volcanism and climate.

\section{Reference}

Braitseva OA, Ponomareva VV, Sulerzhitsky LD, Melekestsev IV, Bailey J (1997) Holocene key-marker tephra layers in Kamchatka, Russia. Quaternary Res 47:125-139

M. Portnyagin $(\square)$

Leibniz Institute of Marine Sciences (IFM-GEOMAR) at Kiel University, Wischhofstr. 1-3, 24148 Kiel, Germany

e-mail: mportnyagin@ifm-geomar.de

\section{Ponomareva}

Institute of Volcanology and Seismology, Piip Bvd. 9, Petropavlovsk-Kamchatsky 683006, Russia

(C) Springer-Verlag 2011 